\title{
INSTRUCTIONAL DESIGN IN TEACHING ENGLISH FOR LAW (A Project Based Learning Instruction in English II for Law Science Department)
}

\author{
Ummi Kultsum and Qosim Arsadani ${ }^{1}$ \\ Permalink: https://www.academia.edu/9997988
}

\begin{abstract}
Abstrak: Desan Intruksional Dalam Pengajaran Bahasa Inggris Hukum. Fakultas Syariah dan Hukum telah mulai mempersiapkan siswa mampu dalam menghadapi karir mereka sebagai ilmuwan hukum tidak hanya di nasional tetapi juga internasional. Kurikulum terpadu telah menjadi pilihan sebagai sistem pendidikan. Salah satu bentuk kurikulum terpadu adalah untuk mengkorelasikan antara atau di antara mata pelajaran. Untuk memenuhi hal ini, fakultas mencoba untuk mengembangkan Program ESP sebagai program pikiran dalam proses pembelajaran. Desain pembelajaran merupakan salah satu pendekatan yang dapat menjadi metode pilihan untuk dosen bahasa Inggris dalam memberikan subjek. English II diajarkan di kedua semester.
\end{abstract}

Kata kunci: ESP Program, desain instruksional, Pengajaran Bahasa Inggris Hukum, Pembelajaran Berbasis Proyek (PBL).

Abstract: Intructional Design In Teaching English For Law. Sharia and Law faculty has started to prepare its students able in facing their career as a law scientist not only in national but also international. Integrated curriculum has become a define choice as educational system aims for rigor and relevance. One of the forms of integrated curriculum is to correlate between or among subjects. To fulfill this, the faculty tries to develop ESP program as the mind program in learning process. Instructional design is one of the approaches that can be an option method for English lecturer in delivering the subject. English II is taught in the second of semester. This subject is being correlated under the notion of Project Based Learning (PBL). The design involves students totally to search, analyze, and conclude what they learn. This will make students doing what they learn, and then they will understand what they make.

Keywords: ESP Program, Instructional design, Teaching English for Law, Project Based Learning (PBL)

* Diterima tanggal naskah diterima: 10 Juli 2014, direvisi: 20 Oktober 2014, disetujui untuk terbit: 9 November 2014.

${ }^{1}$ Faculty of Sharia and LAW. UIN Syarif Hidayatullah. Jl.Ir. H. Juanda No.95 Ciputat Jakarta. E-mail: ummiwahyudi@gmail.com 


\section{Preface}

This article discusses about an instructional design that has been developed in teaching learning English at Sharia and Law faculty. Sharia and Law Faculty is the icon of UIN Syarif Hidayatullah and Islamic economy is a barometer in the world (Suma. 2013). Therefore, teaching English becomes significance to be taught in this department. There is English for Specific purpose as an appropriate program to deliver the content of material based on the field of students and English is a tool to strengthen their knowledge.

In learning process, she tried to develop the teaching learning by using an appropriate text that she builds in a guidance book. From there, students read and tried to analyze what the text was talking about. After that, some students will work individually, pair or group to solve some questions that mentioned in the book. Some difficult words will be discussed later with the lecturer or looking then in a dictionary. Therefore, during the lesson, lecturer asked them to bring a dictionary either printed or online.

However, there were still many weaknesses that found in the teaching learning above. There were seldom of students that were active to learn, discuss and propose questions. Also, not all students have high motivation in learning because they think it was very hard reading those texts. As the result, they just busy only in translating the text.

To answer this, the writer tries to find another teaching methodology in order to reach the learning target. One of the methodologies is Instructional Learning (IL). This methodology developed to integrate both English as a skill and the science or field of materials that students have. IL has be design to follow many different of student's learning style.

Learning design includes a wide range of activities that share the common element of -involving students in doing things and thinking about the things; they are doing (Bonwell \& Eison 1991). Learning design can be created and used to engage students in (a) thinking critically or creatively, (b) speaking with a partner, in a small group, or with the entire class, (c) expressing ideas through writing, (d) exploring personal attitudes and values, (e) giving and receiving feedback, and (f) reflecting upon the learning process. It should also be noted that active learning instructional can (a) be completed by students either in-class or out-of-class, (b) be done by students working either as individuals or in group, and (c) be done either with or without the use of technology tools.

When an instructor employs active learning strategies, he or she will typically will (a) spend greater proportion of time helping students develop their understanding and skills (promoting deep learning) and a lesser proportion of time transmitting information (i.e., supporting surface learning). In addition, the instructor will provide opportunities for students to (a) apply and demonstrate what they are learning and to (b) receive immediate feedback from peers and/or the instructor.

This becomes very crucial in order for law students to fulfill their knowledge by reading, searching or finding some cases that happen around the 
world. From that information, they will learn critically and develop their analysis on anything they have hear, read and discuss. Thus, they could understand many international Law terminologies from that.

One of the strategy from Instructional design is Project based Learning (PBL), where students are accommodated to build a project to enhance their knowledge. By developing a project, students can learn and do any information they have. In PBL, they will search, analyze, and decide the problem and make their own conclusion of the problems they have.

\section{English for Specific Purpose}

English for Specific Purposes (ESP) is the teaching by using a special topic appropriate with the occupied areas of learners' study. ESP program combines scientific fields with English. It can motivate students because they can learn English at the same time they apply their knowledge based on their scientific field. Their skills in a particular field will ultimately improve their English achievement. The subject / materials will finally provide the context of understanding that they need to learn English (Hutchinson dan Waters. 1990; Mackay and Mountford. 1992; Morrison. 2001).

In Indonesian context, English for Specific Subject; starting from the preparation of the subject matter up to the implementation in class. As it is explained that objective of occupation learning are creating and designing a student with certain skill proficiency used in work skill. So the objective of the subject matter should also support it. Additionally, BSNP (2006) (Badan Standar Nasional Pendidikan or national standards used in designing course) defined the content standard of ESP program that are: a). Mastering the basic knowledge and skills to support the achievement of English language competency skills program. B). Implementing mastery skills in English to communicate both orally and in writing at the intermediate level.

Based on the two purposes above, ESP definitely concern to support the skill or proficiency in the work field and the teaching learning process in vocational school. This also becomes a concern for non-English department in University.

\section{Instructional Design (ID)}

As it is discussed at the background, ID can be created and used to engage students in (a) thinking critically or creatively, (b) speaking with a partner, in a small group, or with the entire class, (c) expressing ideas through writing, (d) exploring personal attitudes and values, (e) giving and receiving feedback, and (f) reflecting upon the learning process.

To transform them into a strategy of learning, they are some steps that can be followed as a guidance of teaching in ID Strategy (Cruikshank, Bainer \& Metcalf, 1999):

1. Academic games or competition- Learners compete with each other one to-one or team to-team to determine which individual or group is superior at a given task like project competition. 
2. Activity- a general teaching method (e.g., problem solving, design challenge, field trips, role playing) based on planned, purposeful involvement of students.

3. Brainstorming- order to generate creative ideas, learners are asked to withhold judgment or criticism and produce a very large number of ways to do something, such as resolve a problem.

4. Case study- A detailed analysis is made of some specific, usually compelling event or series of related events so that learners will better understand its nature and what might be done about it.

5. Centers of interest and displays- Collections and displays of materials are used to interest learners in themes or topics. For example, children may bring to school and display family belongings that reflect their ethnic heritage. The intention may be to interest the class in the notion of culture. Alternatively, the teacher might arrange a display of different devices used in measurement to prompt interest in that topic.

6. Colloquia- A guest or guests are invited to class for being interviewed in order to find out about the persons or activities in which they are involved. Thus, a guest musician might serve as a stimulus for arousing interest in music and musical performance.

7. Contract- Written agreements entered into by students and teachers that describe academic work to be accomplished at a particular level ill a particular period such as a week or month.

8. Controversial Issues- An issues-based, teacher-directed method that focuses on controversies. Students are directed through a process that assists them in understanding how to deal with controversial and sensitive issues and clarifies these issues in a group context. Involves critical thinking and discourse analysis.

9. Cooperative learning- Learners are placed in groups of four to six. Sometimes the groups are as diverse or heterogeneous as possible. In such cases, group members are often rewarded for the group's overall success. Student groups might be given a teacher presentation on division of fractions. They would then be given worksheets to complete. Team members would first help and then quiz one another.

10. Culture jamming- A methods used to empower students to "speak back" to mass advertisements and media images that enforce stereotypes and select representations of individuals or groups. Empowers students to mock or "jam" images of popular culture.

11. Debate- A form of discussion whereby a few students present and contest varying points of view with regard to an issue.

12. Debriefing- A method used to provide an environment or platform for the expression of feelings and transfer of knowledge following an experience. Debriefing may come at the hands of a tragic event or may be used more generally following an intentionally educational experience. Debriefing relies on the skills of the facilitator to reframe an experience or event to appropriately channel emotions and knowledge toward understanding and transformation. 
13. Demonstration- A teaching method based predominantly on the modeling of knowledge and skills. A form of presentation whereby the teacher or learners show how something works or operates, or how something is done.

14. Direct instruction- A term used to describe explicit, step-by-step instruction directed by the teacher.

15. Discovery or inquiry- Discovery learning is used when students are encouraged to derive their own understanding or meaning for something.

16. Discussion- Discussions occur when a group assembles to communicate with one another through speaking and listening about a topic or event of mutual interest.

17. Drill and practice- A form of independent study whereby, after the teacher explains a task, learners practice it.

18. Feedback- A semi-formal mode of communicating to students constructive criticism regarding their performance during an activity

19. Field observation, fieldwork, field trip- Observations made or work carried on in a natural setting. Students visit the local museum of natural history to see displays about dinosaurs, or they begin and operate a small business to learn about production and marketing.

20. Independent study or supervised study- Described in this chapter, independent study occurs when learners are assigned a common task to be completed at their desk or as a home study assignment.

21. Individualized instruction- Any of a number of teaching maneuvers whereby teaching and learning are tailored to meet a learner's unique characteristics.

22. Installation- Students present material within a formal structure for displaying audio, multimedia or visual artifacts.

23. Module- A module is a self-contained and comprehensive instructional package, meaning that basically everything that the student needs is in the module. A form of individualized instruction whereby students use a self-contained package of learning activities that guides them to know or to be able to do something. Students might be given a module containing activities intended to help them understand good nutrition.

24. Mastery learning- As a class, students are presented with information to be learned at a predetermined level of mastery. The class is tested and individuals who do not obtain high enough scores are re-taught and retested. Those who passed undertake enrichment study while classmates catch up.

25. Mixed-mode instruction- A combination of "face-to-face" and on-line methods.

26. On-line instruction and learning- A self-directed and automated approach that utilizes hypermedia (internet browsers, etc.) for communication that generally provides independence from the architectural constraints of classrooms. 
27. Performance- Students act out through dance, drama, music or other expressive forms.

28. Presentation and lecture- Students listen to a person who talks about a topic. To illustrate, the teacher, or a guest speaker, tells the class all about the invention of the transistor.

29. Problem- A general teaching method and organization of curriculum and knowledge where students work purposefully toward a solution, synthesis or cause. Often called problem-based learning.

30. Programmed and automated instruction- A form of individualized instruction whereby information is learned in small, separate units either by way of reading programmed texts or using computer-based programs.

31. Project- Students work through a series of activities and problems culminating in the completion of something tangible (e.g., artifact, media, performance). A form of individualization whereby learners choose and work on projects and activities that facilitate and support the development of skills and knowledge. Often, learners not only choose topics but also the means of their conduct and production.

32. Protocols- Learners study an original record or records of some important event and then try to understand the event or its consequences. They might watch a film depicting actual instances of discrimination and then consider its causes and effects.

33. Recitation- Students are given information to study independently. They then recite what they have learned when questioned by the teacher.

34. Reports, written and oral- Individuals or groups of learners are given or choose topics.

35. Role playing- Learners take on the role of another person or character to see what it would be like to be that person or character.

36. Simulation game- Students play a specially designed, competitive game that mirrors some aspect of life. For example, they might play the Ghetto Game to find out about the problems and pressures that ghetto dwellers face and to sense how difficult it is to improve one's lot in life.

37. Simulation- Learners engage with something intended to give the appearance or have the effect of something else.

38. Synectics- The use of specific techniques to foster creativity in students.

39. Tutoring- A form of individualization whereby either a teacher, or perhaps a fellow student, provides a learner or small group of learners with special help, usually because they are not learning well enough with only conventional instruction.

40. Unit- An intentionally designed, integrated, thematic organization of curriculum and knowledge through combinations of demonstrations, discussions, activities, problems, and projects.

41. Values clarification- Teachers lead students through a series of moral and ethical dilemmas, such as birth control or clear-cutting forestry practices, to assist them in clarifying their values and moral choices. 


\section{Instructional Design in FSH (Learning English through Project Based Learning/PBL)}

ID is used in teaching English for Law in FSH that will be focused on reading, speaking and writing. These skills are the appropriate skills that students should have after they graduated from university.

In reading strategy, students will be asked to collect some articles, cases, or news related to their field. They will read critically in order to understand deeply about what they read. After that, they will discuss in-group and presented in front of the class. This might needs cooperation with other law lecturers that will guide students to find an appropriate text before they decide it and discuss it with others.

In speaking strategy, students will be oriented to present their reading comprehension and give the opinion about the text. Other students will give the feedback a question, rebuttal or disagreement. This process will motivate them to express their idea about the topic.

The last is writing. In this term, each student will make a resume or a small essay about the discussion. Later the lecturer will give the feedback about what they wrote weekly after the discussion. The English structure will be developed here.

Project based learning here is to accommodate those skills above. In learning English based on PBL, students have been asked to develop a project. A magazine was their project this time. From making magazine, they start learning how to search, read, critic, and write the topic they have chosen. Later on, they also can present those topics to express their understanding about the issues.

\section{Research methodology}

This research is designed using qualitative descriptive method. Participants of this research are 30 students from Law Science department, second semester who were taking English II subject. They are chosen because they have English II where reading becomes the orientation of the learning. Data were gathered through questioner. The data collected was codified, classified and interpreted.

The research has been taking for four months, including the developing of student's project. Magazine was the project conducted by students.

There are some steps in doing the study; 1 ). Students being asked to find and decide the issues that they could discuss them with the class; 2). Students made an article and presented it on the class; 3 ). Students gave the feedback from the discussion they have done; 4). Students made magazines from the article they have made before

\section{Research finding}

The question items were included in the questionnaire is divided in three parts. The first part related to participants' profile. The second part is a part of getting pertinent information on English II subject. The last part related 
to the obstacles and expectation of participants about the lesson they have taken.

\section{Students Questioner (getting pertinent information on learning English based on PBL)}

In the acquisition of data, researchers conducted observations and questionnaires. These instruments related to the effectiveness of learning. The questionnaires are distributed to the students to evaluate the program design and content of teaching and the relevance of the needs of the topics taught.

In order to obtain data regarding learning English based on PBL made more interesting. Data obtained from 30 students, 97\% (29 students) agreed that learning through PBL was interesting and other 3\% (1 student) has not give her/his comment.

Related to the question of team work in learning based on PBL, 94\% (28 students) agreed that work in team has developed in doing the project. But 1 student (3\%) disagrees about it and other $3 \%$ gave no comment.

Regarding to learning English based on PBL made it more meaningful, 84\% (25 students) said that learning English based on PBL gave learning English become more meaningful. However, 6\% (2 students) disagreed about it. And the rest of $10 \%$ (3 Students) abstain.

The students who assumed developing their ability in searching and studying information from learning English based on PBL during learning process are; $94 \%$ (28 students), $6 \%$ (2 students) gave no comment on it. Furthermore, 77\% (23 students) felt that in learning English based on PBL, they can learn other materials outside of the lesson. Even 13\% (4 students) disagreed about it and the rest of $10 \%$ (3 students) abstain.

Related to statement of learning English based on PBL can accommodate student's learning style. 64\% (19 students) agreed, but 23\% (7 students) disagreed and 13\% (4 students) abstain.

However, 90\% (27 students) assumed that learning English based on PBL made them more responsible in their learning process, meanwhile 10\% (3 students) of them abstain.

This is further strengthened by the questions relating to learning English based on PBL made 80\% (25 students) can control learning and become an independent learner. Only 10\% (3 students) did not feel it and the rest of $10 \%$ (3 students) did not give their response.

At last, there were $85 \%$ (25) students assumed that learning English based on PBL increased their speaking and writing ability. 13\% (4) Students did not think so and only 3\% (1) students abstain. Thus, learning English based on PBL made them think critically. This can be seen that $71 \%(21$ students) agreed about it. 16\% (5 students) disagreed and the rest of 3\% (3 students) gave no response.

\section{Students Questioner (the obstacles and expectation of students about the lesson they have taken)}

To retrieve data information about student's obstacle (difficulties) and expectation in learning English based on PBL, researchers open some questions 
for stimulating students to express their experience during the class and also their ideas about the class they have taken.

On the first question, students being asked about the difficulties in learning English based on PBL. Most of students felt difficulties when they have to work in a group. Different person will show different personality. This makes them hard to elaborate their ideas and decide the appropriate issue in a group. Other problem they have faced was how to manage their time in developing their project. However, during the time they started know how to manage their time for finding the issues, searching the data to support them, put them in an article and later make the pointer which they would presented in front of the class.

Second question, students have been asked about their motivation in learning English based on PBL. All students mentioned that they have high motivation in learning English based on PBL. Most of them felt that they understand more clearly about the materials of Public Speaking and writing. Thus, they have new lesson about how to make a magazine.

This supported to the third question whether learning English based on PBL promoted students to learn other materials. Students stated that bay learning English based on PBL, they can learn how to be a journalist, understand social life, education, culture, law and even medicine. Furthermore, students agreed in learning English based on PBL they learn how to develop the communications among others whether in the group or in the class.

Next, students have asked about their impression about learning English based on PBL. All of students thought that learning English based on PBL were very interesting and impressing. According to them, PBL is a new way/strategy in learning. The lessons they have were very appropriate to be delivered with this strategy. Thus, they could do two different subjects in one project. Even it was hard for the first time, but this made them aware and serious to learn any materials.

Therefore, students asked the researchers to keep doing the learning strategy (PBL) in their teaching-learning process. Even, they suggested to support other lecturer to use the same strategy in other lesson. And for learning English based on PBL could be varieties to not only make a magazine but make a film, drama or else.

\section{Conclusion}

Integrated curriculum has become a define choice as educational system aims for rigor and relevance. One of the forms of integrated curriculum is to correlate between or among subjects. English two subjects that taught in the second of semester. This subject is being correlated under the notion of Project Based Learning (PBL).

By using qualitative descriptive design, the study found that learning English based on PBL can develop students motivation in learning the subject, give them the opportunity to learn other subjects outside the two subjects such as journalistic, social live, education, culture and so on. Thus, this provides the 
real purpose of learning. Also, learning English based on PBL reduces student's burden in doing tasks.

Form the research and the finding above, it can be concluded integrated learning that pointed in integrated curriculum will support students to increase their learning quality. Thus, they can develop the real learning because they understand what they do.

\section{Sources}

Carver, D. 1983. Some Propositions about ESP. The ESP Journal, 2. Day, Jeremy. And Mark Krazanowski. 2011. Teaching English for Specific Purposes: An Introduction. Cambridge: Cambridge University Press

Dewi, Ratna Sari. 2012. Needs Analysis of ESP for Educational Students. Jakarta: Lemlit

Doyle, T. (2008). Helping students learn in a learner-centered environment: A guide to facilitating learning in higher education. Sterling, VA: Stylus Publishing.

Driscoll, M. 1994. Psycology of Learning for Instruction. Boston: Allyn an Bacon.

Dudley-Evans, T. \& St. John, M. 1998. Developments in ESP: A Multidisciplinary approach. Cambridge: Cambridge University Press

Fahriany. 2009. ESP Reading Materials. A Developmental Study at Agribusiness Program Faculty of Science and Technology UIN Syarif Hidayatullah. Jakarta: Thesis of Post Graduate Program at State University of Jakarta.

Griffith, R, T. 2002. History of the Internet, Internet for historians (and just about everyone else). Chapter three: History of the electronic mail. Retrieved May $3^{\text {rd }}$, 2013, from http://www.let.leidenuniv. nl/history/ivh/chap3.htm

Hutchinson \& Waters. 1990. The Study of Language Acqusition. New York. Oxford University Press

Kultsum, Ummi. 2012. Analisis kebutuhan (needs analysis) Mahasiswa Fakultas Syariah UIN Syarif Hidayatullah. Jakarta: Lemlit

Morrison, Harry. 2001. English for Specific Purpose. New York: Harper Collins College Publishers.

Nunan, David. 1987. The Teacher as Curriculum Developer: An Investigation of Curriculum Processes within the Adult Migrant Education Program. South Australia: National Curriculum Resources Center

Richards, Jack, C. 2001. Curriculum development in language teaching. Course planning and syllabus design. New York: Cambridge University Press.

Richards, Jack, C. 2005. Materials Development and Research-Making the Connection. Paper presented at a colloquium on rserach and materials development, at the TESOL Convention. San Antonio

Robinson, Clare. 1988. Teaching ESP. Englewood Cliff: Prentice Hall

Tim,Bowen. 2010. Teaching approaches: task-based learning. Retrieved May $8^{\text {th }}, 2013$, from. 